\title{
CORPORATE SOCIAL RESPONSIBILITY: CONTRIBUTION / ROLE OF PAKISTAN ARMY'S PESHAWAR DIVISION IN KHYBER PAKHTUN KHUWA (KPK) - PAKISTAN
}

\author{
Mr. Rumman Iqbal Khattak ${ }^{1}$ and Mr. Jamshed Khaliq ${ }^{2}$ \\ ${ }^{1}$ Department of Engineering Management, Abasyn University, Peshawar, Pakistan \\ ${ }^{2}$ Department of Management Sciences, Abasyn University, Peshawar, Pakistan
}

DOI: 10.46609/IJSSER.2020.v05i10.024 URL: https://doi.org/10.46609/IJSSER.2020.v05i10.024

\begin{abstract}
The study purely aims to illuminate and explore the role/ work of Army in carried/ carrying out CSR activities in province of KPK, Pakistan. Data is collected from already published various sources i.e. portals, newspapers and on ground observation etc. which is processed to generate a firm conclusion based on the same data. Findings confirm the dominant involvement of Army in carrying out CSR activities in KPK contributes to the wellbeing of local sand strengthening trust of the people on Army besides their core responsibility.
\end{abstract}

Keywords: Corporate social responsibility, Wellbeing of people, Defense forces.

\section{Introduction}

Corporate social responsibility (CSR) are actions of an organization and policies that takes several sorts of expectations, stakeholders and the triple bottom line of social, economic \& environment into account (Aguinis \& Glavas, 2012)has been always a pivotal focus of organizations (H. L. Kim, Rhou, Uysal, \& Kwon, 2017). Corporate social responsibility (CSR) may be described as facultative steps of an org that enhance societal welfare beyond the requirement by law (Korschun, Bhattacharya, \& Swain, 2014; McWilliams \& Siegel, 2001). The CSR studies evolved to take CSR initiatives as primarily pertaining to welfare of people (Park, Song, \& Lee, 2017), recipient behavior (Li, Liu, \& Huan, 2019), residents' attitudes and support (Lee, Kim, \& Kim, 2018). Over the decades firms have engage their selves in tasks that have been regarded as true governmental activities traditionally (Margolis and Walsh, 2003; Matten and Crane, 2005; Scherer and Palazzo, 2008) takes part in improvement of public health, social security, education and human rights protection where as mostly operating in region with collapsed systems (Matten and Crane, 2005); handles, undernourishment, shelterlessness and illiteracy etc (Margolis and Walsh, 2003; Rosen et al., 2003); and encourage societal stability 
International Journal of Social Science and Economic Research

ISSN: 2455-8834

Volume:05, Issue:10 "October 2020"

\&peace (Fort and Schipani, 2004). Moreover, CSR also boosts up morale of the employees engaged in CSR activities (Ghaderi, Z., Mirzapour, M., Henderson, J. C., \& Richardson, S. 2019). Socially, what seems to be a generic paradigm (de Grosbois, 2012), respondents perceives that CSR is a way of welfare, support for community and societal well-being along with protection of local culture \& heritage. Every organization acknowledged and began taking obligations about society. Wealth creation for the maximum gain of all shareholders i.e. customers, employees, society and environment is prime focus of corporate social responsibility (CSR). Asper Bowen, the obligations of businessmen to adopt policies that leads to follow the lines of relations, which are favorable in terms of objectives and values of our society is said to be CSR. Frederick (1960) declared CSRis the operation of an economic system monitored by businessmen for fulfillment of expectations of society. Social performance of a firm is reflected by this operational perspective of CSR, evaluation of the same may be carried out by how societal relationships of a firm to be managed, its social influence and outcomes of CSR policies and actions (Wood, 1991). A defense organization has long been excluded from the circle of CSR just because a very limited information is available on its role in the field of CSR. In Pakistan, the defense institute is playing a role parallel to all the civil business institute regarding CSR. This study will cover the role of the Peshawar Division regarding CSR in KPK, an enriched province of the Islamic Republic of Pakistan.

\section{Purpose and scope of study}

The study under consideration aims to enlighten the role of Pakistan defense organizations, particularly Peshawar division in carrying out CSR activities for development, improvement of living standard, better medical care in Khyber Pakhtun Khuwa (KPK).

\section{Objectives of the study}

To explore how Peshawar Division of Pak Army fulfills/ fulfilled their responsibility towards community/ society; what specific activities project have been executed/ developed and implemented by them.

\section{Research Methodology}

A through literature survey in connection with topic and concerned concepts were carried out. Moreover, Secondary data was collected from various sources including books, research papers, newspapers, magazines and websites is used for the purpose of study.

\section{Background of The Province Khyber Pakhtun Khuwa (KPK), Pakistan}

a. Geography. Khyber Pakhtun khuwa is one of the four provinces of Pakistan. It borders the Gilgit-Baltistan in north-east, in east it connects to Azad Kashmir, in south-east it joins Punjab\& 
International Journal of Social Science and Economic Research

ISSN: $2455-8834$

Volume:05, Issue:10 "October 2020"

Islamabad (Capital Territory), whereas Afghanistan in north-west. Moreover, Baluchistan is located southwards of KPK. Peshawar is declared as capital city of the province.

b. History. The estimated population of province is recorded as 21 million approx. Pushtuns being biggest ethnic, historically have been living since ancient days in said areas. Afghan refugees almost 1.5 million is also shares major part population. As per 1998 census, population of province was almost 17 million, out of which $52 \%$ and $48 \%$ were found to be males and females respectively.

c. Agencies and Frontier Regions. The province of KPK also comprise of recently included Federal Administrative Tribal Areas/ agencies i.e. Mohmand Agency, Bajaur Agency, Khyber Agency, Orakzai Agency, North Waziristan Agency, Kurram Agency, South Waziristan Agency) and 6 frontier zonesi.e Peshawar, Kohat, Bannu, Lakki, Tank and DI Khan.

6. The Pakistan Army's Peshawar Division. The Peshawar division of the Pakistan army has always contributed in coping with uncertain situation/ disasters/ earth quacks over all in province of KPK and also played an important part in facilitating the locals. Moreover, Peshawar division is particularly deployed in the province to fulfill their key responsibilities but besides that they always led from the front in CSR activities..

\section{Pak Army's Peshawar Division and Corporate Social Responsibility (CSR).}

\section{a. Infrastructure Development}

(1) Roads. A total length of $673 \mathrm{Km}$ metallic roads were constructed in 2019 to interconnect various towns and agencies spending around $\mathrm{Rs} 54.597 \mathrm{Bn}$. In addition to roads a $4.5 \mathrm{~km}$ of numerous bridges were also constructed spending around Rs $79.18 \mathrm{Bn}$ under supervision of Peshawar division. Some of the famous roads includes:-
(a) Road Wana - Makeen (76 Km)
(b) Road Wana - A/Adda (55 Km)
(c) Road Jandola- Makeen $(110 \mathrm{Km})$
(d) Road Tank- Wana (105 Km)

(2) Health. In the past 5 years, Peshawar Division has spent sufficient amount in the field of health and care. In these 5 years the Peshawar division manage to build 31 health care units / hospitals in KPK single handedly, spending around Rs 2155.5 Mn out of their own resources. These $31 \mathrm{x}$ health care and hospitals are distributed throughout the KPK ( 2 x Swat, 1 x Bajur, 11 $\mathrm{x}$ South Waziristan Agency, $17 \mathrm{x}$ North Waziristan Agency) so as to ensure timely health facilities to local population. Some state of the art hospitals include:- 
International Journal of Social Science and Economic Research

ISSN: 2455-8834

Volume:05, Issue:10 "October 2020"
(a) Sheikh Zaid Hospital $600 \mathrm{x}$ beds
(b) Khar Hospital $423 \times$ beds
(c) THQ Mir Ali Hospital $110 \mathrm{x}$ beds
(d) Laddah Hospital $10 \mathrm{x}$ beds
(e) Sholam Hospital $50 \mathrm{x}$ beds
(f) Tui Khula Hospital $40 \mathrm{x}$ beds

(3) Schools. Education is most important element of social development in any country. Peshawar division has invested heavily to uplift the education facility in KPK. In past 5 years a total of $185 \mathrm{x}$ education projects has been completed spending around Rupees 3906.56 Mn. Aim is to target the most effected population in the entire province reaching every corner of the region (52 x Swat, $2 \times$ Bajur, $60 \times$ South Waziristan Agency, 1 x Mohmand Agency, $70 \times$ North Waziristan Agency). Some of the pronounced education institutes constructed by the Peshawar division includes:-
(a) Cadet College Wana SWA
(b) Cadet College Swat
(c) Girls Middle School NWA
(d) Army Public School Shakai SWA

(4) Water Schemes. The rural areas of most of the agencies and far flung villages are deprived of clean drinking water and had been key problem since decades. The Peshawar Division in the last 5 years completed a total of 317 water supply schemes in KPK by spending Rs $2392.32 \mathrm{Mn}$. Focus was to benefit large populations and construct water supply schemes in major areas where it can supply a number of villages and towns. Distribution of these 317 WSS is Malakand - 24, Bajur - 20, Mohmand - 10, NWA - 115, SWA-148. Major WSS projects includes:-
(a) Water Supply Scheme Bajur
(b) Water Supply Scheme NWA
(c) Dhana Irrigation Scheme
(d) Water Supply Scheme SWA

(5) Fata Youth Program. The Peshawar decision has been instrumental in providing numerous education and employment opportunities to youth of Federal administered tribal areas (FATA) 
International Journal of Social Science and Economic Research

ISSN: 2455-8834

Volume:05, Issue:10 "October 2020"

now part of KPK. In the past 5 years, a total of 2800 students has been passed out from Cadet Colleges, 3000 from Army Public school systems, 5827 has been qualified in Tech Trainingby tech institutes in the region. In addition to education opportunities, 1500 youth has been employed in Army, 7400 youth employed in Frontier Corps and 50 youth employed abroad through funding of the Peshawar division. A total of $987 \mathrm{Mn}$ has been spend on youth development program. The further progress of the students which graduated from cadet colleges in KPK region is that $16.84 \%$ joined Pakistan Armed Forces, $17.02 \%$ joined Medical universities, $18.45 \%$ joined Engineering universities, $11.82 \%$ got into Private sector, $35.84 \%$ got miscellaneous field of employment.

(6) Religious places. The Peshawar decision also looks after the uplift / beautification of religious places that fall under their jurisdiction / area of responsibility. $145 \mathrm{Mn}$ have been spent on religious places. Some of the major uplift of these religious education setup includes:-

(a) Rahim Mosque

(b) Tableeghi Mosque

(c) Al Faiz Mosque

(d) Madina Mosque

(7) Markets / utility shops. As the rural population is very poor and has limited opportunities of earning, the Peshawar division invested in construction of shops and uplift of market places and made them available for rent / owner ship so that people get a decent mode of earing and a good source of employment. These includes 67 major markets in NWA \& SWA spending around Rs. $543 \mathrm{Mn}$ in addition $787 \mathrm{x}$ shops have been constructed. Next 5 year plan includes 2000 shops in Mir Ali, 2150 shops in Miran Shah and 750 shops in Makeen.

(8) Sports facilities. A healthy mind resides in a healthy body, keeping that in view numerous minor and major sports facilities have been developed by the Peshawar decision so as to provide a recreational / healthy activity for the locals. 433 Mn have been spent on sports facilities. Most outstanding of all is the Younas Khan Sports Complex - Nwa which includes an International standard cricket stadium having a Spectators capacity of5000. Other facilities in this sports complex includes $2 \times$ Football grounds, 2 x Basketball courts, 2 x Hockey grounds and $1 \mathrm{x}$ Badminton court.

8. Summary - CSR Activities. The Peshawar Division has spent a lot in context of CSR specifically in KPK province. Pakistan Army just like any other corporate businesses very well deserve to be the role model in CSR. Summarize data of CSR activities is appended below:- 


\section{International Journal of Social Science and Economic Research}

ISSN: 2455-8834

Volume:05, Issue:10 "October 2020"

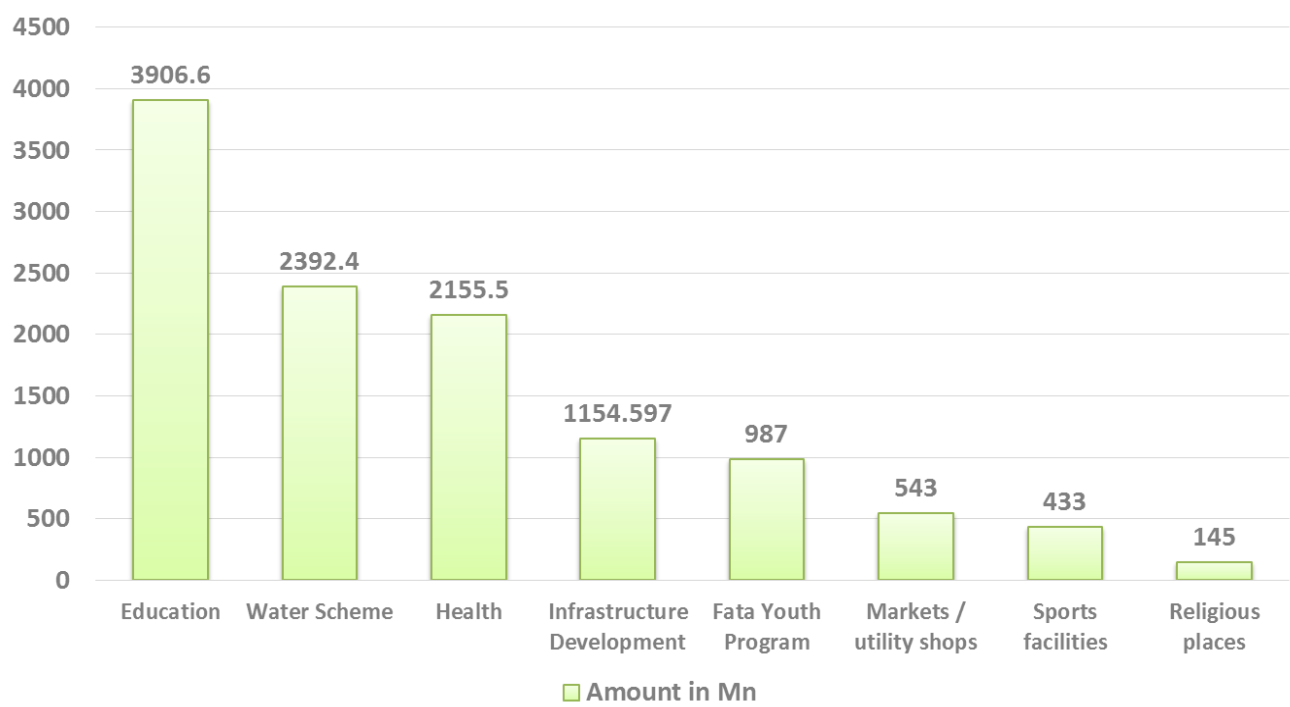

\section{Graph - I}

The graph shows the most predominant area which was improved was the education sector $(33.30 \%)$ whereas the least focus area was the improvement of religious places $(1.20 \%)$. In term of the total percentage of funds consumed can be seen below:-

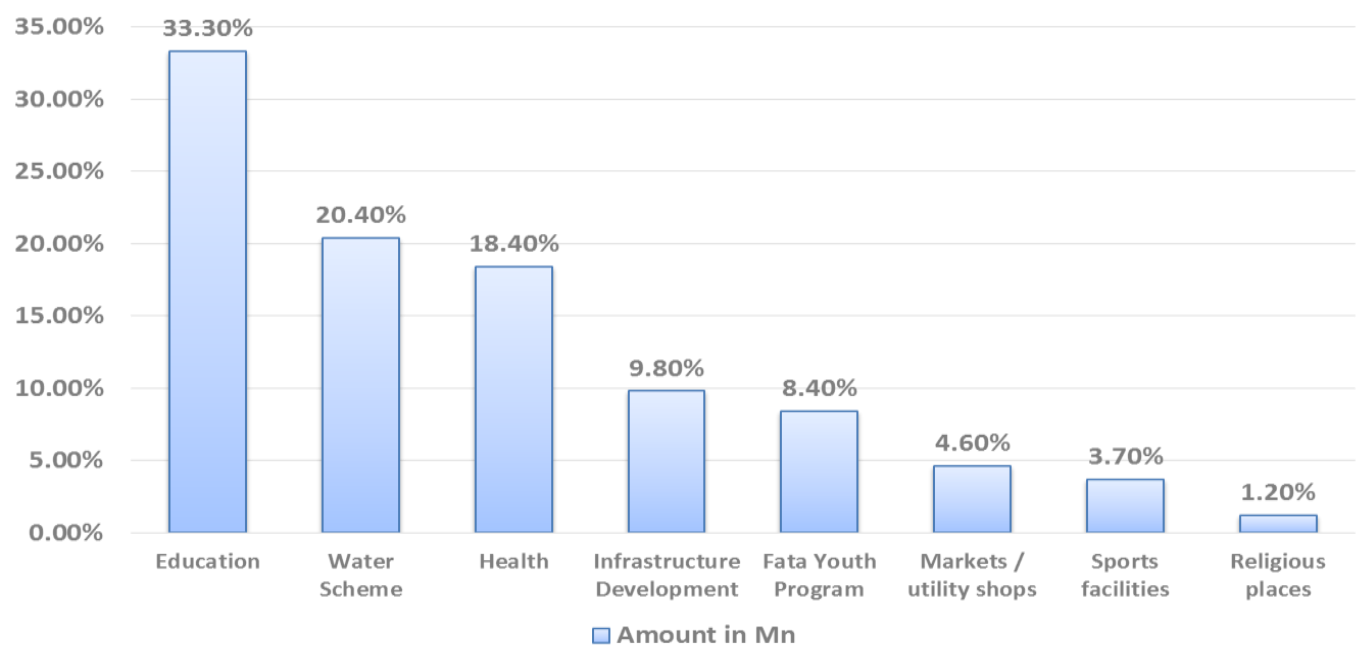




\section{International Journal of Social Science and Economic Research}

ISSN: $2455-8834$

Volume:05, Issue:10 "October 2020"

\section{Conclusion}

To maintain the general balance in economic and social arena, it is evident to think profoundly and act wisely about CSR. Every organization owe some responsibility towards the society and nation in general it look after somehow all human, material and natural resources. Pakistan Army is committed to social development within the geographical boundaries of Pakistan. In Khyber Pakhtun Khuwa, in addition to performing the internal security duties, the Pakistan ArmyPeshawar Division is actively playing its role to contribute towards the betterment of the society. Moreover, involvement of Army in CSR activities also strengthens the trust of the people on their forces. Keeping in view long run growth and sustainable development following norms of CSR, devising new policies and effective implementation is unavoidable to bring a balance and maintain same between organizations and society, man and nature. An organization of firm is not claimed to be diverted from core duties or to be more generous, altruistic and philanthropic than others but CSR activities must also be made a part of organization's motive.

\section{Limitations}

While execution ofthe study, names and the location of sub headquarter of the Peshawar Division is not mentioned purely due to confidential status. Role of Pakistan Army as a whole with regards to CSR need to be studied in-depth to cover more facts overall in the country.

\section{References}

Aguinis, H., \& Glavas, A. (2012). What we know and don't know about corporate social responsibility: A review and research agenda. Journal of management, 38(4), 932-968.

Kim, H. L., Rhou, Y., Uysal, M., \& Kwon, N. (2017). An examination of the links between corporate social responsibility (CSR) and its internal consequences. International Journal of Hospitality Management, 61, 26-34.

Ghaderi, Z., Mirzapour, M., Henderson, J. C., \& Richardson, S. (2019). Corporate social responsibility and hotel performance: A view from Tehran, Iran. Tourism Management Perspectives, 29, 41-47.

De Grosbois, D. (2012). Corporate social responsibility reporting by the global hotel industry: Commitment, initiatives and performance. International Journal of Hospitality Management, 31(3), 896-905.

Frederick, W. C. (1960). The growing concern over business responsibility. California management review, 2(4), 54-61. 


\section{International Journal of Social Science and Economic Research}

ISSN: $2455-8834$

Volume:05, Issue:10 "October 2020"

Wood, D. J. (1991). Corporate social performance revisited. Academy of management review, 16(4), 691-718.

Halpern, B. H., \& Snider, K. F. (2012). Products that kill and corporate social responsibility: The case of US defense firms. Armed Forces \& Society, 38(4), 604-624.

Pratt, A., Rendon, R., \& Snider, K. (2011). Public procurement and corporate social responsibility: a comparison of private firms and US defense contractors. In Proceedings of the 5th International Public Procurement Conference, Boca Raton, FL (pp. 3750-3772).

Halpern, B. H. (2008). Corporate social responsibility orientation: An investigation of specific Department of Defense contractors (Doctoral dissertation, Capella University).

Khan, N., Shah, S. J., Rauf, T., Zada, M., Yukun, C., \& Harbi, J. (2019). Socioeconomic impacts of the billion trees afforestation program in Khyber Pakhtunkhwa Province (kpk), Pakistan. Forests, 10(8), 703.

Wood, D. J. (1991). Corporate social performance revisited. Academy of management review, 16(4), 691-718.

Margolis, J. D., \& Walsh, J. P. (2003). Misery loves companies: Rethinking social initiatives by business. Administrative science quarterly, 48(2), 268-305.

Crane, A., \& Matten, D. (2005). Corporate citizenship: Missing the point or missing the boat? A reply to van Oosterhout. Academy of Management Review, 30(4), 681-684.

Palazzo, G., \& Scherer, A. G. (2008). Corporate social responsibility, democracy, and the politicization of the corporation. Academy of Management Review, 33(3), 773-775.

Margolis, J. D., \& Walsh, J. P. (2003). Misery loves companies: Rethinking social initiatives by business. Administrative science quarterly, 48(2), 268-305.

Fort, T. L., \& Schipani, C. A. (2004). The role of business in fostering peaceful societies. Cambridge University Press.

Wood, D. J. (1991). Corporate social performance revisited. Academy of management review, 16(4), 691-718. 